\title{
PERAN KEPUASAN KERJA DALAM MEMEDIASI PENGARUH WORK FAMILY CONFLICT DAN KOMPENSASI TERHADAP TURNOVER INTENTION
}

\author{
Made Chintya Mahadewi ${ }^{1}$ \\ Agoes Ganesha Rahyuda ${ }^{2}$
}

Fakultas Ekonomi dan Bisnis Universitas Udayana, Bali, Indonesia ${ }^{1,2}$

Email: tyamahadewi@gmail.com ${ }^{1}$

\begin{abstract}
The Role of Job Satisfaction in Mediating The Effect of Work Family Conflict and Compensation Towards Turnover Intention. The purpose of this study is to analyze the effect of work family conflict, compensation, and job satisfaction on turnover intention, to analyze the effect of work family conflict and compensation on job satisfaction, and to analyze the role of job satisfaction in mediating the effect of work family conflict and compensation on turnover intention. This research was conducted at the Permata Bank Dewi Sartika Branch Denpasar, the number of samples used was 93 employees, using the proportional random sampling method. The analysis technique used was path analysis. The software used is SPSS 22. The results show that work family conflict has a positive and significant effect on turnover intention, compensation and job satisfaction has a negative and significant effect on turnover intention, work family conflict has a negative and significant effect on job satisfaction, compensation positive effect on job satisfaction, job satisfaction is able to mediate the effect of work family conflict and compensation for turnover intention on Bank Permata Dewi Sartika Denpasar Branch employees.
\end{abstract}

Keywords: turnover intention; job satisfaction; work family conflict; compensation.

\begin{abstract}
Abstrak: Peran Kepuasan Kerja dalam Memediasi Pengaruh Work Family Conflict dan Kompensasi Terhadap Turnover Intention. Tujuan dari penelitian ini adalah untuk menganalisis pengaruh work family conflict, kompensasi ,dan kepuasan kerja terhadap turnover intention, untuk menganalisis pengaruh work family conflict dan kompensasi terhadap kepuasan kerja, serta untuk menganalisis peran kepuasan kerja dalam memediasi pengaruh work family conflict dan kompensasi terhadap turnover intention. Penelitian ini dilakukan di Bank Permata Cabang Dewi Sartika Denpasar, jumlah sampel yang digunakan yaitu 93 orang karyawan, dengan menggunakan metode proporsionate random sampling .Teknik analisis yang digunakan adalah analisis jalur (path analysis). Software yang digunakan adalah SPSS 22. Hasil penelitian menunjukan bahwa work family conflict memiliki pengaruh yang positif dan signifikan terhadap turnover intention, kompensasi dan kepuasan kerja memiliki pengaruh yang negatif dan signifikan terhadap turnover intention,work family conflict berpengaruh negatif dan signifikan terhadap kepuasan kerja, kompensasi berpengaruh positif terhadap kepuasan kerja, kepuasan kerja mampu memediasi pengaruh work family conflict dan kompensasi terhadap turnover intention pada karyawan Bank Permata Cabang Dewi Sartika Denpasar.
\end{abstract}

Kata kunci: turnover intention; kepuasan kerja; work family conflict; kompensasi. 


\section{PENDAHULUAN}

Turnovermengarah padakenyataan akhir yang dihadapi suatu organisasi berupa jumlah karyawan yang meninggalkan organisasi pada periode tertentu, sedangkan keinginan karyawan untuk berpindah (turnover intention) mengacu pada hasil evaluasi individu mengenai kelanjutan hubungan dengan organisasi yang belum di wujudkan dalam tindakan pasti meninggalkan organisasi (Putra \& Wibawa, 2015). Turnover intention merupakan saat seorang karyawan memiliki kecenderungan untuk berhenti dari pekerjaannya (Robbins \& Judge 2007: 38), turnover (berpindah kerja) biasanya merupakan salah satu pilihan terakhir bagi seorang karyawan apabila ia mendapati kondisi kerjanya sudah tidak sesuai lagi dengan apa yang diharapkannya. Berdasarkan hasil wawancara dengan 6 orang karyawan di Bank Permata Cab. Dewi Sartika Denpasar, dimana rata-rata alasan para karyawan memutuskan keluar dari pekerjaannya karena pekerjaan yang dipikul terlalu berat atau mengalami overload pekerjaan sehingga karyawan sulit untuk menyeimbangkan tanggung jawab untuk pekerjaan dan untuk keluarga, alasan lainnya adalah gaji dan tunjangan yang diberikan oleh perusahaan lain dinilai karyawan lebih baik dari pada gaji dan tunjangan yang diberikan oleh Bank Permata itu sendiri.

Berbagai penelitian telah dilakukan mengenai hubungan antara work family conflict terhadap turnover intention, yaitu diantaranya work family conflict memiliki pengaruh yang positif dan signifikan terhadap turnover intention, dimana pengaruh positif mengisyaratkan apabila work family conflict yang dialami oleh karyawan meningkat, maka turnover intention karyawan juga ikut meningkat. Berbagai penelitian telah dilakukan mengenai hubungan antara work family conflict terhadap turnover intention misalnya, Wulandari \& Adnyani (2016) dalam penelitiannya mengatakan bahwa work family conflict berpengaruh positif terhadap turnover intention, Dewi dkk. (2018) menyatakan bahwa work-family conflict berpengaruh positif dan signifikan terhadap turnover intention, Nanda \& Utama (2015) juga berpendapat bahwa work family conflict berpengaruh positif dan signifikan terhadap turnover intention karyawan. Selain itu Chen et al., (2018) dalam penelitiannya menyatakan bahwa WIF (work interfence with family) dan FIW ( family interfence in work) keduanya memiliki hubungan yang positif terhadap niat untuk berpindah. 
Sependapat dengan hal tersebut Long et al., (2016) mengemukakan bahwa work family conflict memiliki hubungan yang positif dengan turnover intention, dimana work family conflict adalah salah satu faktor yang mempengaruhi karyawan untuk meninggalkan organisasi. Riptiono (2019) dalam penelitiannya menyatakan bahwa work family conflict berpengaruh positif terhadap variabel turnover intention, dimana work-family conflict yang tinggi akan meningkatkan turnover intention, Nisa \& Malik (2016) dalam penelitiannya menunjukan pengaruh positif signifikan antara variabel work family conflict dan turnover intention. Pengaruh yang positif dan signifikan mengindikasikan dengan semakin tingginya work family conflict yang dirasakan oleh karyawan, maka akan semakin meningkatkan kecenderungan karyawan melakukan turnover.

Berbagai penelitian telah dilakukan mengenai hubungan antara kompensasi dengan turnover intention, dimana diantaranya penelitian yang dilakukan oleh Widayati \& Yunia (2016) yaitu kompensasi berpengaruh negatif dan signifikan terhadap turnover intention, hal serupa diungkapkan oleh Pranowo (2016) menyatakan kompensasi berpengaruh negatif terhadap turnover intention karyawan yang dimana semakin tinggi kompensasi yang diberikan maka semakin rendah turnover intention karyawan. Penelitian yang dilakukan oleh Arta \& Surya (2017) mengungkapkan kompensasi memiliki pengaruh negatif dan signifikan terhadap turnover intention. Selaras dengan hal tersebut Artiningrum \& Satrya (2016) mengemukakan bahwa kepuasan gaji yang didapat karyawan dapat menurunkan tingkat turnover intention. Selaras dengan hal tersebut Chew et al., (2016) dalam penelitiannya mengatakan bahwa terdapat korelasi yang signifikan antara variabel kompensasi dengan turnover, dimana dengan semakin rendahnya kompensasi yang diberikan makan akan turnover intention akan semakin meningkat.

Penelitian yang dilakukan oleh Candra et al., (2018) menyatakan bahwa terdapat hubungan yang negatif antara variabel Kompensasi dengan variabel turnover intention, hal tersebut selaras dengan penelitian yang dilakukan oleh Rubel \& Kee (2015) yang menyatakan bahwa terdapat hubungan yang negatif antara variabel kompensasi dengan turnover intention, penelitian yang dilakukan oleh Fuaidah dkk., (2018) mengungkapkan 
bahwa kompensasi karyawan berpengaruh negatif dan signifikan terhadap turnover intention. Jadi, jika terjadi perubahan terhadap kerja.

kompensasi maka akan berpengaruh terhadap perubahan turnover intention.

Selain work family conflict dan kompensasi, kepuasan kerja adalah salah satu hal yang harus diperhatikan oleh atasan atau manajer di suatu perusahaan, dimana menurut Mangkunegara (2005: 117) kepuasan kerja berhubungan dengan variabel-variabel seperti turnover, tingkat absensi, umur, tingkat pekerjaan, dan ukuran organisasi perusahaan. Kepuasan kerja berhubungan dengan turnover mengandung arti bahwa kepuasan kerja yang tinggi selalu dihubungkan dengan turnover pegawai yang rendah, dan sebaliknya jika pegawai banyak yang merasa tidak puas maka turnover pegawai tinggi. Selaras dengan hal tersebut Sutrisno (2009: 75) mengungkapkan bahwa karyawan yang tidak memperoleh kepuasan kerja tidak akan pernah mencapai kepuasan psikologis dan akhirnya akan timbul sikap atau tingkah laku negatif dan pada gilirannya akan dapat menimbulkan frustasi. Sebaliknya karyawan yang terpuaskan akan dapat bekerja dengan baik, penuh semangat, aktif, dan dapat berprestasi lebih baik dari karyawan yang tidak memperoleh kepuasan

Berbagai penelitian telah membahas mengenai hubungan antara variabel kepuasan kerja dengan variabel turnover intention, yaitu penelitian yang dilakukan oleh Rismayanti dkk., (2018) menyebutkan terdapat arah hubungan negatif antara kepuasan kerja dengan turnover intention, dimana arah hubungan yang negatif menunjukkan jika variabel kepuasan kerja karyawan semakin baik atau meningkat maka variabel turnover intention karyawan juga akan semakin menurun. Selaras dengan hal tersebut penelitian yang dilakukan oleh Sathyanarayan dan Lavanya (2018) menyatakan adanya hubungan yang negatif dan signifikan antara variabel kepuasan kerja dengan turnover intention, Lee \& Chelladurai (2017) dalam penelitiannya juga menyatakan adanya hubungan yang negatif antara variabel kepuasan kerja dengan variabel turnover intention, Zeffane \& Melhem (2017) dalam penelitiannya mengatakan adanya hubungan yang kuat antara variabel kepuasan kerja dengan variabel turnover intention, serta penelitian yang dilakukan oleh Zhang et al., (2018) menyatakan bahwa terdapat 
pengaruh yang negatif antara variabel kepuasan kerja dengan variabel turnover intention.

Penelitian yang dilakukan oleh Ardiyanti (2019); Turgut et al., (2017); Widyantara \& Ardana (2015); Putra \& Mujiati (2019) juga menunjukan hasil yang sama dimana kepuasan kerja berpengaruh negatif terhadap turnover intention. Dengan kata lain, semakin tinggi tingkat kepuasan yang dirasakan karyawan dengan pekerjaannya maka semakin rendah tingkat keinginan karyawan untuk keluar meninggalkan pekerjaannya.

Selanjutnya terdapat pengaruh antara variabel work family conflict dengan variabel kepuasan kerja, dimana telah banyak peneliti yang melakukan penelitian mengenai hubungan variabel tersebut, yaitu antara lain penelitian yang dilakukan oleh Paramita \& Subudi (2017) menunjukkan hasil bahwa konflik pekerjaankeluarga berpengaruh negatif terhadap kepuasan kerja. Selaras dengan hal tersebut penelitian yang dilakukan oleh Mardhika \& Dewi (2019) menjelaskan bahwa konflik pekerjaan keluarga berpengaruh negatif dan signifikan terhadap kepuasan kerja.

Hasil penelitian yang dilakukan oleh Ariana \& Riana (2016); Afrilia \& Utami (2018) menunjukan pengaruh negatif dan signifikan antara work family conflict terhadap kepuasan kerja karyawan. Zito et al., (2019) menyatakan terdapat pengaruh yang negatif antara variabel work family conflict dengan variabel kepuasan kerja, Rahman etal., (2018) dalam penelitiannya juga menyatakan terdapat hubungan yang negatif antara variabel work family conflict dan kepuasan kerja. Hal serupa diungkapkan oleh Yani dkk., (2016) Work-family conflict memiliki pengaruh langsung yang negatif terhadap kepuasan kerja artinya dengan semakin rendah work-family conflict yang dirasakan karyawan maka akan semakin meningkatkan kepuasan kerja.

Selain variabel work family conflict, variabel kompensasi juga dapat mempengaruhi variabel kepuasan kerja, dimana telah banyak peneliti melakukan penelitian mengenai hubungan antara variabel kompensasi dengan kepuasan kerja, salah satunya adalah Potale \& Uhing (2015) yang dalam penelitiannya menyatakan kompensasi berpengaruh positif dan signifikan terhadap kepuasan kerja karyawan. Hal serupa diungkapkan oleh Akmal \& Tamini (2015) dimana upah pokok secara parsial mempunyai hubungan yang positif dan 
signifikan terhadap kepuasan kerja. Tantowi dkk., (2016) mengemukakan bahwa kompensasi finansial memberikan pengaruh positif terhadap kepuasan kerja karyawan.

Variabel kepuasan kerja dapat memediasi variabel work family conflict dan kompensasi terhadap variabel turnover intention, dimana telah banyak peneliti yang melakukan penelitian, yaitu Wulandari \& Adnyani (2016) dalam penelitiannya memperoleh hasil bahwa work-family conflict berpengaruh negatif parsial terhadap turnover intention melalui mediasi kepuasan kerja. Selanjutnya penelitian yang dilakukan oleh Sakawangi \& Supartha (2017) memperoleh hasil bahwa kepuasan kerja memediasi secara parsial dan positif pada pengaruh konflik pekerjaan-keluarga terhadap keinginan keluar karyawan, hal serupa juga diungkapkan oleh Paramita \& Subudi (2017) menunjukkan bahwa peran mediasi kepuasan kerja pada pengaruh konflik pekerjaankeluarga terhadap turnover intention yaitu positif dan signifikan, selanjutnya penelitian yang dilakukan oleh Tariana \& Wibawa (2016) membuktikan bahwa kepuasan kerja memediasi work family conflict terhadap turnover intention karyawan wanita di PT. Bank Rakyat Indonesia
(Persero) Tbk. Cabang Denpasar. Silvyana \& Wibawa (2019)dengan teknik purposive random sampling. Pengumpulan data diperoleh dari wawancara dan penyebaran kuesioner. Teknik analisis data yang digunakan adalah structural equation model (SEM dalam pengujian hipotesis pada peran kepuasan kerja memediasi pengaruh work-family conflict terhadap turnover intention berpengaruh positif dan kepuasan kerja memediasi secara parsial.

Work family conflict memiliki pengaruh yang positif dan signifikan terhadap turnover intention, dimana pengaruh positif mengisyaratkan apabila work family conflict yang dialami oleh karyawan meningkat, maka turnover intention karyawan juga ikut meningkat. Berbagai penelitian telah dilakukan mengenai hubungan antara work family conflict terhadap turnover intention misalnya, Wulandari \& Adnyani (2016) dalam penelitiannya mengatakan bahwa work family conflict berpengaruh positif terhadap turnover intention, Dewi dkk., (2018) menyatakan bahwa work-family conflict berpengaruh positif dan signifikan terhadap turnover intention. Nanda \& Utama (2015) juga berpendapat bahwa work family conflict berpengaruh positif dan signifikan 
terhadap turnover intention karyawan. Selain itu Chen et al., (2018) dalam penelitiannya menyatakan bahwa WIF (work interfence with family) dan FIW ( family interfence in work) keduanya memiliki hubungan yang positif terhadap niat untuk berpindah.

Sependapat dengan hal tersebut Long et al., (2016) mengemukakan bahwa work family conflict memiliki hubungan yang positif dengan turnover intention, dimana work family conflict adalah salah satu faktor yang mempengaruhi karyawan untuk meninggalkan organisasi. Riptiono (2019) dalam penelitiannya menyatakan bahwa work family conflict berpengaruh positif terhadap variabel turnover intention, dimana work-family conflict yang tinggi akan meningkatkan turnover intention, Nisa \& Malik (2016) dalam penelitiannya menunjukan pengaruh positif signifikan antara variabel work family conflict dan turnover intention. Pengaruh yang positif dan signifikan mengindikasikan dengan semakin tingginya work family conflict yang dirasakan oleh karyawan, maka akan semakin meningkatkan kecenderungan karyawan melakukan turnover, maka hipotesis adalah sebagai berikut:

H1: work family conflict berpengaruh positif dan signifikan terhadap turnover intention.

Kompensasi berpengaruh negatif dan signifikan terhadap turnover intention karyawan, yang dimana hal ini mengisyaratkan semakin tingginya kompensasi yang diberikan perusahaan kepada karyawannya maka niat keluar karyawan akan semakin rendah. Berbagai penelitian telah dilakukan mengenai hubungan antara kompensasi dengan turnover intention, dimana diantaranya dilakukan oleh Widayati \& Yunia (2016) yaitu kompensasi berpengaruh negatif dan signifikan terhadap turnover intention, hal serupa diungkapkan oleh Pranowo (2016) menyatakan kompensasi berpengaruh negatif terhadap turnover intention karyawan yang dimana semakin tinggi kompensasi yang diberikan maka semakin rendah turnover intention karyawan. Penelitian yang dilakukan oleh Arta \& Surya (2017) mengungkapkan kompensasi memiliki pengaruh negatif dan signifikan terhadap turnover intention. Selaras dengan hal tersebut Artiningrum \& Satrya (2016) mengemukakan bahwa kepuasan gaji yang didapat karyawan dapat menurunkan tingkat turnover intention. Selaras dengan hal tersebut Chew et al., (2016) dalam penelitiannya mengatakan bahwa terdapat korelasi yang 
signifikan antara variabel kompensasi dengan turnover, dimana dengan semakin rendahnya kompensasi yang diberikan makan akan turnover intention akan semakin meningkat.

Penelitian yang dilakukan oleh Candra et al., (2018) menyatakan bahwa terdapat hubungan yang negatif antara variabel Kompensasi dengan variabel turnover intention, hal tersebut selaras dengan penelitian yang dilakukan oleh Rubel \& Kee, (2015) yang menyatakan bahwa terdapat hubungan yang negatif antara variabel kompensasi dengan turnover intention, penelitian yang dilakukan oleh Fuaidah dkk., (2018) mengungkapkan bahwa kompensasi karyawan berpengaruh negatif dan signifikan terhadap turnover intention. Jadi, jika terjadi perubahan terhadap kompensasi maka akan berpengaruh terhadap perubahan turnover intention, maka hipotesis adalah sebagai berikut:

H2: Kompensasi berpengaruh negatif dan signifikan terhadap turnover intention.

Kepuasan kerja berpengaruh negatif terhadap turnover intention yang dimana hal ini mengisyaratkan dengan semakin tingginya tingkat kepuasan kerja yang dirasakan karyawan, maka turnover intention akan menurun. Berbagai penelitian telah membahas mengenai hubungan antara kepuasan kerja dengan turnover intention, yaitu penelitian yang dilakukan oleh Rismayanti dkk., (2018) menyebutkan terdapat arah hubungan negatif antara kepuasan kerja dengan turnover intention, dimana arah hubungan yang negatif menunjukkan jika variabel kepuasan kerja karyawan semakin baik atau meningkat maka variabel turnover intention karyawan juga akan semakin menurun. Selaras dengan hal tersebut penelitian yang dilakukan oleh Sathyanarayan \& Lavanya (2018) menyatakan adanya hubungan yang negatif dan signifikan antara variabel kepuasan kerja dengan turnover intention, Lee \& Chelladurai (2017) dalam penelitiannya juga menyatakan adanya hubungan yang negatif antara variabel kepuasan kerja dengan variabel turnover intention, Zeffane \& Melhem (2017) dalam penelitiannya mengatakan adanya hubungan yang kuat antara variabel kepuasan kerja dengan variabel turnover intention, serta penelitian yang dilakukan oleh Zhang et al., (2018) menyatakan bahwa terdapat pengaruh yang negatif antara variabel kepuasan kerja dengan variabel turnover intention.

Penelitian yang dilakukan oleh 
Ardiyanti (2019); Turgut et al., (2017), dan signifikan terhadap kepuasan kerja.

Widyantara \& Ardana (2015); Putra \& Mujiati (2019) juga menunjukan hasil yang sama dimana kepuasan kerja berpengaruh negatif terhadap turnover intention. Dengan kata lain, semakin tinggi tingkat kepuasan yang dirasakan karyawan dengan pekerjaannya maka semakin rendah tingkat keinginan karyawan untuk keluar meninggalkan pekerjaannya, maka hipotesis adalah sebagai berikut:

H3: Kepuasan kerja berpengaruh negatif dan signifikan terhadap turnover intention.

Work family Conflict berpengaruh negatif terhadap kepuasan kerja karyawan, yang dimana hal ini mengisyaratkan dengan semakin tingginya work family conflict yang dialami oleh karyawan makan semakin menurunnya kepuasan kerja yang dirasakan oleh karyawan. Dimana sudah banyak peneliti yang melakukan penelitian mengenai hubungan variabel tersebut yaitu antara lain penelitian yang dilakukan oleh Paramita \& Subudi (2017) menunjukkan hasil bahwa konflik pekerjaan-keluarga berpengaruh negatif terhadap kepuasan kerja. Selaras dengan hal tersebut penelitian yang dilakukan oleh Mardhika \& Dewi (2019) menjelaskan bahwa konflik pekerjaan keluarga berpengaruh negatif
Hasil penelitian yang dilakukan oleh Ariana \& Riana (2016); Afrilia \& Utami (2018) menunjukan pengaruh negatif dan signifikan antara work family conflict terhadap kepuasan kerja karyawan. Zito et al., (2019) menyatakan terdapat pengaruh yang negatif antara variabel work family conflict dengan variabel kepuasan kerja Rahman et al., (2018) dalam penelitiannya juga menyatakan terdapat hubungan yang negatif antara variabel work family conflict dan kepuasan kerja. Hal serupa diungkapkan oleh Yani dkk., (2016) Work-family conflict memiliki pengaruh langsung yang negatif terhadap kepuasan kerja artinya, dengan semakin rendah work-family conflict yang dirasakan karyawan maka akan semakin meningkatkan kepuasan kerja, maka hipotesis adalah sebagai berikut:

H4: Work family conflict berpengaruh negatif dan signifikan terhadap kepuasan kerja.

Kompensasi berpengaruh positif dan signifikan terhadap kepuasan kerja, hal ini mengisyaratkan bahwa dengan semakin baiknya kompensasi yang diberikan maka akan semakin tinggi pula tingkat kepuasan kerja yang dirasakan oleh karyawan. Dimana Potale \& Uhing (2015) yang dalam penelitiannya 
menyatakan kompensasi berpengaruh positif dan signifikan terhadap kepuasan kerja karyawan. Hal serupa diungkapkan oleh Akmal \& Tamini (2015) dimana upah pokok secara parsial mempunyai hubungan yang positif dan signifikan terhadap kepuasan kerja. Tantowi dkk., (2016) mengemukakan bahwa kompensasi finansial memberikan pengaruh positif terhadap kepuasan kerja karyawan.

Selanjutnya penelitian yang dilakukan oleh Ramli (2018) menyatakan terdapat pengaruh yang positif dan signifikan antara variabel kompensasi terhadap variabel kepuasan kerja, Ganesan et al., (2017) juga menyatakan bahwa variabel kompensasi berpengaruh positif dan signifikan dengan variabel kepuasan kerja, Wasistha dan Rahyuda (2018); Nurcahyani \& Adnyani (2016) juga menyatakan kompensasi berpengaruh positif dan signifikan terhadap kepuasan kerja pegawai. Hal yang serupa juga diungkapkan oleh Setyorini et al., (2018) dalam penelitiannya menyatakan bahwa terdapat pengaruh yang positif dan signifikan antara variabel kompensasi dengan variabel kepuasan kerja pada PT. Bank Rakyat Indonesia Tbk, kota Denpasar, maka hipotesis adalah sebagai berikut:
H5: Kompensasi berpengaruh positif dan signifikan terhadap kepuasan kerja.

Pengaruh work family conflict terhadap turnover intention bersifat berlawanan, yang dimana hal ini mengisyaratkan dengan semakin tingginya work family conflict yang dirasakan oleh karyawan, maka akan semakin menurunkan tingkat kepuasan kerja karyawan. Wulandari \& Adnyani (2016) dalam penelitiannya memperoleh hasil bahwa work-family conflict berpengaruh negatif parsial terhadap turnover intention melalui mediasi kepuasan kerja. Selanjutnya penelitian yang dilakukan oleh Sakawangi \& Supartha (2017) memperoleh hasil bahwa kepuasan kerja memediasi secara parsial dan positif pada pengaruh konflik pekerjaan-keluarga terhadap keinginan keluar karyawan, hal serupa juga diungkapkan oleh Paramita \& Subudi (2017) menunjukkan bahwa peran mediasi kepuasan kerja pada pengaruh konflik pekerjaan-keluarga terhadap turnover intention yaitu positif dan signifikan, selanjutnya penelitian yang dilakukan oleh Tariana \& Wibawa (2016) membuktikan bahwa kepuasan kerja memediasi work family conflict terhadap turnover intention karyawan wanita di PT. Bank Rakyat Indonesia (Persero) Tbk. 
Cabang Denpasar. Silvyana dan Wibawa (2019) dalam pengujian hipotesis pada peran kepuasan kerja memediasi pengaruh work-family conflict terhadap turnover intention berpengaruh positif dan kepuasan kerja memediasi secara parsial, maka hipotesis adalah sebagai berikut:

H6: Kepuasan kerja memediasi pengaruh work family conflict terhadap turnover intention.

Kompensasi sangat berpengaruh terhadap kepuasan kerja karyawan. dengan semakin tingginya kompensasi yang diberikan perusahaan kepada karyawan, maka kepuasan kerja yang dirasakan karyawan akan semakin meningkat, dimana dengan meningkatnya kepuasan kerja karyawan akan menurunkan keinginan karyawan untuk meninggalkan perusahaan tempatnya berada sekarang. Penelitian yang dilakukan oleh Rohmawati dkk., (2017) mengungkapkan kepuasan kerja dapat memediasi pengaruh dari kompensasi terhadap intensitas turnover. mediasi yang diberikan bersifat parsial, artinya kompensasi dapat berpengaruh secara langsung terhadap intensitas turnover namun juga dapat berpengaruh dengan melalui mediasi kepuasan kerja. Selaras dengan hal tersebut Rasyid \& Indarti (2017) berpendapat bahwa secara tidak langsung kompensasi melalui kepuasan kerja memiliki pengaruh yang signifikan terhadap turnover intention. Semakin baik dan memuaskan kompensasi karyawan, maka secara tidak langsung akan memberikan perasaan puas dalam bekerja, maka semakin rendah tingkat keinginan mereka keluar dari perusahaan, dalam artian bahwa turnover intention akan menurun pada karyawan. Robbin (2015: 52) menyatakan bahwa kompensasi sangat berkorelasi dengan kepuasan kerja dan juga kepuasan kerja akan berdampak terhadap keinginan karyawan untuk keluar (turnover intention) dari perusahaan.

Menurut penelitian yang dilakukan oleh Agustin (2018) kepuasan kerja dapat disebut sebagai mediasi parsial antara variabel kompensasi finansial langsung dan variabel turnover intention, hal ini berarti bahwa apabila kompensasi finansial langsung semakin baik dan kepuasan kerja semakin tinggi, maka turnover intention yang terjadi akan semakin rendah. Sedangkan penelitian yang dilakukan oleh Yudhistira \& Pradana (2016) menyatakan bahwa kompensasi berpengaruh secara tidak langsung terhadap turnover intention, sedangkan kepuasan kerja tidak dapat memediasi hubungan pengaruh antara kompensasi dan turnover 
intention. Hal ini disebabkan kompensasi memiliki pengaruh terhadap turnover intention sedangkan kepuasan kerja tidak memiliki pengaruh terhadap turnover intention, maka hipotesis adalah sebagai berikut:

H7: Kepuasan kerja memediasi pengaruh kompensasi terhadap turnover intention.

\section{METODE PENELITIAN}

Penelitian ini dilakukan di Bank Permata cab. Dewi Sartika Denpasar, yang berlokasi di Jl. Dewi Sartika No. kav. 88, Dauh Puri Kauh, Kecamatan Denpasar Barat, Kota Denpasar, Bali, yang melatar belakangi pemilihan lokasi ini adalah karena belum banyak yang melakukan penelitian di perusahaan tersebut mengenai sumber daya manusianya, dan ditemukan masalah yang berkaitan dengan turnover intention, work family conflict, kompensasi, serta kepuasan kerja. Obyek dari penelitian ini adalah turnover intention, work family conflict, kompensasi, dan kepuasan kerja pada karyawan Bank Permata, cab. Dewi Sartika Denpasar.

Populasi dalam penelitian ini adalah seluruh karyawan Bank Permata Cab. Dewi Sartika Denpasar yang berjumlah 122 orang. Jumlah sampel yang diambil dalam penelitian ini menggunakan rumus Slovin. Penggunaan rumus slovin karena peneliti hanya membutuhkan sampel untuk mewakili dari seluruh populasi, adapun rumus slovin yaitu sebagai berikut:

$n=\frac{\mathrm{N}}{1+N e^{2}}$

Keterangan:

$n$ = Jumlah sampel

$\mathrm{N}=$ Jumlah populasi

$\mathrm{e}=$ Jumlah Toleransi kesalahan sebesar 0,05

Jumlah populasi Bank Permata Cab. Dewi

Sartika adalah 122 orang, sehingga:

$\mathrm{n}=\frac{122}{1+(122)\left(0.05^{2}\right)}=93,48$

Berdasarkan rumus slovin jumlah sampel yang di dapat 93,48 dibulatkan menjadi 93 responden.

Penelitian ini menggunakan teknik analisis jalur atau disebut sebagai Path Analysis. Teknik analisis jalur ini akan digunakan dalam menguji besarnya kontribusi yang dinyatakan oleh koefisien jalur pada setiap diagram jalur dari hubungan kausal atau sebab akibat yang tercipta dari variabel eksogen terhadap variabel endogen. Pada dasarnya perhitungan koefisien jalur membutuhkan perhitungan dari analisis korelasi dan regresi yang kemudian dituangkan dalam software berupa SPSS for windows.

Persamaan Sub Struktural 1

$M=p m x 1+p m x 2+e_{1}$ 
Persamaan Sub Struktural 2

$\mathrm{Y}=\operatorname{pyx} 1+\operatorname{pyx} 2+$ pmy $+\mathrm{e}_{2}$

Keterangan:

$\mathrm{X} 1=$ work family conflict

$\mathrm{X} 2$ = kompensasi

$\mathrm{M}=$ kepuasan kerja

$\mathrm{Y}=$ turnover intention

e1 = error of term atau variabel pengganggu

pada variabel kepuasan kerja

e2 = error of term atau variabel pengganggu

pada variabel turnover intention

$\mathrm{p}=$ koefisien korelasi

\section{HASIL DAN PEMBAHASAN}

Pengujian data dalam penelitian ini menggunakan teknik analisis jalur (path analysis), dimana analisis jalur adalah perluasan dari analisis regresi linear berganda untuk menguji hubungan kausalitas antara dua atau lebih variabel.

\section{Tabel 1.}

Hasil Analisis Jalur Persamaan Regresi 1

\begin{tabular}{|c|c|c|c|c|c|}
\hline \multirow[b]{2}{*}{ Model } & \multicolumn{2}{|c|}{$\begin{array}{c}\text { Unstandardized } \\
\text { Coefficients }\end{array}$} & \multirow{2}{*}{$\begin{array}{c}\begin{array}{c}\text { Standardized } \\
\text { Coefficients }\end{array} \\
\text { Beta } \\
\end{array}$} & \multirow[b]{2}{*}{ t } & \multirow[b]{2}{*}{ Sig. } \\
\hline & B & $\begin{array}{l}\text { Std. } \\
\text { Error }\end{array}$ & & & \\
\hline (Constant) & 33.823 & 4.068 & & 8.314 & .000 \\
\hline $\begin{array}{l}\text { WorkFamily } \\
\text { Conflict }\end{array}$ & -.769 & .119 & -.472 & & .000 \\
\hline Kompensasi & .438 & .067 & .480 & 6.569 & .000 \\
\hline $\begin{array}{l}\text { R Square } \\
\text { F hitung } \\
\text { Signifikansi } \\
\text { Uji F }\end{array}$ & $\begin{array}{l}0,534 \\
51,597 \\
0,000\end{array}$ & & & & \\
\hline
\end{tabular}

Persamaan Sub-struktural 1 sebagai berikut:

$\mathrm{M}=-0,472 \mathrm{X}_{1}+0,480 \mathrm{X}_{2}+\mathrm{e}_{\mathrm{i}}$
Tabel 2.

Hasil Analisis Jalur Persamaan Regresi 2

\begin{tabular}{|c|c|c|c|c|c|}
\hline \multirow[b]{2}{*}{ Model } & \multicolumn{2}{|c|}{$\begin{array}{c}\text { Unstandardized } \\
\text { Coefficients }\end{array}$} & \multicolumn{2}{|c|}{$\begin{array}{c}\text { Standardized } \\
\text { Coefficients } \\
\end{array}$} & \multirow[b]{2}{*}{ Sig. } \\
\hline & B & $\begin{array}{l}\text { Std. } \\
\text { Error }\end{array}$ & Beta & $\mathbf{t}$ & \\
\hline (Constant) & 17.006 & 2.714 & & 6.266 & .000 \\
\hline Work & & & & & \\
\hline $\begin{array}{l}\text { Family } \\
\text { Conflict }\end{array}$ & .369 & .072 & 409 & 5.105 & .000 \\
\hline Kompensasi & -.203 & .041 & -.402 & -4.984 & .000 \\
\hline $\begin{array}{l}\text { Kepuasan } \\
\text { Kerja }\end{array}$ & -.116 & .053 & -.209 & -2.185 & .032 \\
\hline R Square & 0,621 & & & & \\
\hline F hitung & 48,666 & & & & \\
\hline Sig. & 0,000 & & & & \\
\hline
\end{tabular}

Sumber : Data diolah, 2020

Persamaan Sub Struktural 2 sebagai berikut:

$\mathrm{Y}=\left(0,409 \mathrm{X}_{1}\right)+\left(-0,402 \mathrm{X}_{2}\right)+(-0,209 \mathrm{M})+\mathrm{e}_{2}$

Pengaruh variabel work family conflict

(X1) terhadap variabel turnover intention (Y) yaitu $\beta 1=0,409$. Pengaruh variabel kompensasi (X2) terhadap variabel turnover intention $(\mathrm{Y})$ yaitu $\beta 2=-0,402$. Pengaruh variabel kepuasan kerja (M) terhadap variabel turnover intention (Y) yaitu $\beta 3=-0,209$. Pengaruh variabel work family conflict (X1) terhadap turnover intention (Y) dengan kepuasan kerja (M) sebagai variabel perantara yaitu:

$$
\begin{aligned}
\mathrm{X} 1 \rightarrow \mathrm{M} \rightarrow \mathrm{Y} & =(\beta 1) \times(\beta 3) \ldots \ldots \\
& =0,409 \times-0,209 \\
& =-0,085
\end{aligned}
$$

Pengaruh variabel kompensasi (X2) terhadap turnover intention (Y) dengan kepuasan kerja (M) sebagai variabel perantara:

$$
\begin{aligned}
\mathrm{X} 2 \rightarrow \mathrm{M} \rightarrow \mathrm{Y} & =(\beta 2) \times(\beta 3) \ldots \ldots \ldots \\
& =-0,402 \times-0,209 \\
& =0,084
\end{aligned}
$$


Pengaruh total $=\beta 1+(\beta 2 \times \beta 3)$

$$
\begin{aligned}
=0,409 & +(-0,402 \times-0,209) \\
& =0,493
\end{aligned}
$$

Menguji nilai koefisien determinasi (R2) dan standard error (e)

$$
\begin{aligned}
& \mathrm{e}_{\mathrm{i}}=\sqrt{1-\mathrm{R}_{\mathrm{i}}{ }^{2}} \\
& \mathrm{e}_{1}=\sqrt{1-{R_{1}}^{2}}=\sqrt{1-0,534}=0,682 \\
& \mathrm{e}_{2}=\sqrt{1-{R_{2}}^{2}}=\sqrt{1-0,621}=0,615
\end{aligned}
$$

Berdasarkan perhitungan pengaruh error (Pei) atau standar error variabel kepuasan kerja, didapatkan hasil pengaruh sebesar 0,682 dan pengaruh error $\left(\mathrm{Pe}_{2}\right)$ atau standar variabel turnover intention didapati hasil sebesar 0,615. Hasil koefisien determinasi total hitung adalah sebagai berikut:

$$
\begin{aligned}
\mathrm{R}_{\mathrm{m}}^{2} & =1-\left(\mathrm{Pe}_{1}\right)^{2}\left(\mathrm{Pe}_{2}\right)^{2} \ldots \ldots \ldots \\
& =1-(0,682)^{2}(0,615)^{2} \\
& =1-(0,465)(0,378) \\
& =0,824
\end{aligned}
$$

Nilai determinasi total sebesar 0,824 mempunyai arti bahwa sebesar 82,4 persen variasi turnover intention dipengaruhi oleh variasi work family conflict, Kompensasi dan Kepuasan kerja, sedangkan sisanya sebesar 17,6 persen djelaskan oleh faktor lain yang tidak dimasukkan ke dalam model.

Berdasarkan hasil pengujian pada Tabel 1 diperoleh nilai $\mathrm{F}$ sebesar 48,666 dengan nilai $(\operatorname{sig})=0,000$. Oleh karena nilai sig $0,000 \leq$
0,05, maka dapat disimpulkan bahwa $\mathrm{H} 0$ ditolak dan $\mathrm{H} 1$ diterima. Artinya bahwa variabel work family conflict, kompensasi, dan kepuasan kerja berpengaruh secara simultan dan signifikan terhadap turnover intention.

Berdasarkan hasil analisis pengaruh work family conflict terhadap turnover intention pada Tabel 2 diperoleh nilai Signifikansi sebesar 0,000, Nilai Sig. 0,000<0,05 mengindikasi bahwa $\mathrm{H}_{0}$ ditolak dan $\mathrm{H}_{1}$ diterima yang berarti terdapat pengaruh yang signifikan antara work family conflict terhadap turnover intention. dengan nilai koefisien beta 0,409 menunjukan arah positif mengindikasikan bahwa work family conflict berpengaruh positif terhadap turnover intention.

Berdasarkan hasil analisis pengaruh Kompensasi terhadap Turnover intention pada Tabel 2 diperoleh nilai Signifikansi sebesar 0,000 dengan nilai koefisien beta $-0,402$ bernilai negatif. Nilai Signifikansi $0,000<$ 0,05 mengindikasikan bahwa $\mathrm{H}_{0}$ ditolak dan $\mathrm{H}_{1}$ diterima. Hasil ini mempunyai arti bahwa Kompensasi berpengaruh negatif dan signifikan terhadap turnover intention.

Berdasarkan hasil analisis pengaruh Kepuasan kerja terhadap turnover intention 
pada Tabel 2 diperoleh nilai Signifikansi sebesar 0,032 dengan nilai koefisien beta -0,209 bernilai negatif. Nilai Signifikansi $0,032<$ 0,05 mengindikasikan bahwa $\mathrm{H}_{0}$ ditolak dan $\mathrm{H}_{1}$ diterima. Hasil ini mempunyai arti bahwa Kepuasan kerja berpengaruh negatif dan signifikan terhadap turnover intention.

Berdasarkan hasil analisis pengaruh work family conflict terhadap kepuasan kerja pada Tabel 1 diperoleh nilai Signifikansi sebesar 0,000 dengan nilai koefisien beta $-0,472$ bernilai negatif. Nilai Signifikansi 0,000< 0,05 mengindikasikan bahwa $\mathrm{H}_{0}$ ditolak dan $\mathrm{H}_{1}$ diterima. Hasil ini mempunyai arti bahwa work family conflict berpengaruh negatif dan signifikan terhadap kepusan kerja.

Berdasarkan hasil analisis pengaruh kompensasi terhadap kepuasan kerja pada Tabel 1 di peroleh nilai Signifikansi sebesar 0,000 dengan nilai koefisien beta 0,480 bernilai positif. Nilai Signifikansi 0,000<0,05 mengindikasikan bahwa $\mathrm{H}_{0}$ ditolak dan $\mathrm{H}_{1}$ diterima. Hasil ini kompensasi terhadap turnover. Jadi pengaruh Tabel 3.

Pengaruh variabel Work Family Conflict $\left(\mathrm{X}_{1}\right)$ terhadap Turnover Intention $(\mathrm{Y})$ dengan Kepuasan kerja (M)

\begin{tabular}{cccc}
\hline Pengaruh Variabel & $\begin{array}{c}\text { Pengaruh } \\
\text { Langsung }\end{array}$ & $\begin{array}{c}\text { Pengaruh Tidak } \\
\text { Langsung }\end{array}$ & Pengaruh Total \\
\hline $\mathrm{X}_{1} \rightarrow \mathrm{Y}$ & 0,409 & 0,099 & 0,510 \\
$\mathrm{X}_{1} \rightarrow \mathrm{M}$ & $-0,472$ & - & $-0,472$ \\
$\mathrm{M} \rightarrow \mathrm{Y}$ & $-0,209$ & - & $-0,209$ \\
\hline
\end{tabular}

mempunyai arti bahwa kompensasi berpengaruh positif dan signifikan terhadap kepusan kerja.

Tabel 3 menunjukkan bahwa pengaruh langsung work family conflict terhadap variabel turnover intention sebesar 0,409 dan pengaruh tidak langsung yang dimediasi oleh kepuasan kerja sebesar 0,099. Jadi pengaruh total variabel work family conflict terhadap turnover intention melalui kepuasan kerja adalah sebesar 0,510. Jadi dapat disimpulkan bahwa lebih besar total pengaruh work family conflict terhadap turnover intention yang melalui kepuasan kerja, dari pada pengaruh langsung work family conflict terhadap turnover intention tanpa melalui variabel Kepuasan kerja.

Tabel 4 menunjukkan bahwa pengaruh langsung kompensasi terhadap turnover intention adalah sebesar -0,402 dan pengaruh tidak langsung yang dimediasi oleh kepuasan kerja sebesar -0,100 ini membuktikan bahwa kepuasan kerja mampu memediasi pengaruh

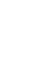


Tabel 4.

Pengaruh variabel Kompensasi $\left(\mathrm{X}_{2}\right)$ terhadap Turnover intention (Y) dengan Kepuasan kerja (M)

\begin{tabular}{cccc}
\hline Pengaruh Variabel & $\begin{array}{c}\text { Pengaruh } \\
\text { Langsung }\end{array}$ & $\begin{array}{c}\text { Pengaruh Tidak } \\
\text { Langsung }\end{array}$ & Pengaruh Total \\
\hline $\mathrm{X}_{2} \rightarrow \mathrm{Y}$ & $-0,402$ & $-0,100$ & $-0,502$ \\
$\mathrm{X}_{2} \rightarrow \mathrm{M}$ & 0.480 & - & 0,480 \\
$\mathrm{M} \rightarrow \mathrm{Y}$ & $-0,209$ & - & $-0,209$ \\
\hline
\end{tabular}

Sumber : Data diolah, 2020

total variabel kompensasi terhadap turnover intention melalui kepuasan kerja adalah sebesar -0,502. Jadi dapat disimpulkan bahwa lebih besar total pengaruh kompensasi terhadap turnover intention melalui kepuasan kerja, dari pada pengaruh langsung kompensasi terhadap turnover intention tanpa melalui variabel Sig(2-tailed) lebih besar dari nilai alpha 0,05. kepuasan kerja.

Uji normalitas bertujuan untuk mengetahui apakah residual dari model regresi yang dibuat berdistribusi normal atau tidak. Untuk menguji apakah data yang digunakan normal atau tidak dapat dilakukan dengan menggunakan uji Kolmogorov-Sminarnov. Apabila koefisien Asymp. Sig (2-tailed) lebih besar dari 0,05 maka data tersebut dikatakan berdistribusi normal.

Tabel 5. Hasil Uji Normalitas Model Struktur 1

\begin{tabular}{lc}
\hline \hline & Unstandardized Residual \\
\hline $\mathrm{N}$ & 93 \\
Kolmogorov-Smirnov & 0,079 \\
Asymp Sig(2-tailed) & 0,200 \\
\hline
\end{tabular}

Sumber : Data diolah, 2020
Berdasarkan Tabel 5 dapat dilihat bahwa nilai Kolmogorov Sminarnov (KS) sebesar 0,079 dan nilai Asymp Sig(2-tailed) sebesar 0,200, hasil tersebut mengindikasikan bahwa model persamaan regresi tersebut berdistribusi normal karena nilai Asymp Tabel 6.

\section{Hasil Uji Normalitas Model Struktur 2}

\begin{tabular}{lc}
\hline & Unstandardized Residual \\
\hline $\mathrm{N}$ & 93 \\
Kolmogorov-Smirnov & 0,052 \\
Asymp Sig(2-tailed) & 0,200 \\
\hline
\end{tabular}

Sumber : Data diolah, 2020

Berdasarkan Tabel 6 dapat dilihat bahwa nilai Kolmogorov Sminarnov (KS) sebesar 0,052 dan nilai Asymp Sig(2-tailed) sebesar 0,200, hasil tersebut mengindikasikan bahwa model persamaan regresi tersebut berdistribusi normal karena nilai Asymp Sig(2-tailed) lebih besar dari nilai alpha 0,05. Uji multikolinearitas digunakan untuk mengetahui ada atau tidaknya penyimpangan asumsi klasik multikolinearitas, yaitu adanya 
hubungan linear antar variabel eksogen dalam model regresi. Uji ini bertujuan untuk menguji apakah pada model regresi ditemukan adanya korelasi antar variabel bebas. Adanya multikolinearitas dapat dilihat dari nilai tolerance atau variance inflation factor (VIF). Jika nilai tolerance lebih dari 10 persen atau VIF kurang dari 10, maka dikatakan tidak ada multikolinearitas.

Tabel 7. Hasil Uji Multikoleniaritas

\begin{tabular}{lcc}
\hline \hline \multicolumn{1}{c}{ Variabel } & Tolerance & VIF \\
\hline Work family conflict $\left(\mathrm{X}_{1}\right)$ & 0,662 & 1,511 \\
Kompensasi $\left(\mathrm{X}_{2}\right)$ & 0,654 & 1,528 \\
Kepuasan kerja $(\mathrm{Y})$ & 0,466 & 2,147 \\
\hline
\end{tabular}

Sumber : Data diolah, 2020

Berdasarkan Tabel 7 dapat dilihat bahwa nilai tolerance dan VIF dari variabel Work family conflict, Kompensasi dan Kepuasan kerja menunjukkan nilai tolerance untuk setiap variabel lebih besar dari 10\% dan nilai VIF lebih kecil dari 10 yang berarti model persamaan regresi bebas dari multikolinearitas.

Uji heterokedastisitas bertujuan untuk mengetahui apakah dalam model regresi terjadi ketidaksamaan varians dari residual satu pengamatan ke pengamatan yang lain dan pengujian ini dilakukan dengan uji glejser. Jika nilai signifikansinya di atas 0,05 maka tidak mengandung gejala heteroskedastisitas.
Tabel 8.

Hasil Uji Heteroskedastisitas Model Struktur 1

\begin{tabular}{|c|c|c|c|c|c|}
\hline \multirow[b]{2}{*}{ Model } & \multicolumn{2}{|c|}{$\begin{array}{c}\text { Unstandardize } \\
\text { Coefficients }\end{array}$} & \multirow{2}{*}{$\begin{array}{r}\begin{array}{c}\text { Standardized } \\
\text { Coefficients }\end{array} \\
\text { Beta }\end{array}$} & \multirow[b]{2}{*}{$\mathbf{T}$} & \multirow[b]{2}{*}{ Sig. } \\
\hline & B & $\begin{array}{c}\text { Std. } \\
\text { Error }\end{array}$ & & & \\
\hline $\begin{array}{ll}1 & \text { (Constant) } \\
\text { Work }\end{array}$ & 3.614 & 2.164 & & 1.670 & .098 \\
\hline $\begin{array}{l}\text { Family } \\
\text { Conflict }\end{array}$ & -.110 & .063 & -.179 & $1.742^{-}$ & .085 \\
\hline Kompensasi & .065 & .035 & .190 & 1.846 & .068 \\
\hline
\end{tabular}

Pada Tabel 8 dapat dilihat bahwa nilai signifikansi dari variabel work family conflict sebesar 0,085. Nilai signifikansi dari variabel kompensasi sebesar 0,068. Nilai tersebut lebih besar dari 0,05 yang berarti tidak terdapat pengaruh antara variabel bebas terhadap absolute residual. Dengan demikian, model yang dibuat tidak mengandung gejala heteroskedastisitas.

Tabel 9. Hasil Uji Heteroskedastisitas Model Struktur 2

\begin{tabular}{|c|c|c|c|c|c|}
\hline \multirow[b]{2}{*}{ Model } & \multicolumn{2}{|c|}{$\begin{array}{l}\text { Unstandardized } \\
\text { Coefficients }\end{array}$} & \multirow{2}{*}{$\begin{array}{c}\begin{array}{c}\text { Standardized } \\
\text { Coefficients }\end{array} \\
\text { Beta }\end{array}$} & \multirow[b]{2}{*}{$\mathbf{T}$} & \multirow[b]{2}{*}{ Sig. } \\
\hline & B & $\begin{array}{l}\text { Std. } \\
\text { Error }\end{array}$ & & & \\
\hline $\begin{array}{ll}1 \text { (Constant) } \\
\text { Work }\end{array}$ & 2.948 & 1.583 & & 1.862 & .066 \\
\hline $\begin{array}{l}\text { Family } \\
\text { Conflict }\end{array}$ & .023 & .042 & .067 & .536 & .593 \\
\hline Kompensasi & -.040 & .024 & -.209 & $1.677^{-}$ & .097 \\
\hline $\begin{array}{l}\text { Kepuasan } \\
\text { Kerja }\end{array}$ & -.020 & .031 & -.097 & -.658 & .512 \\
\hline
\end{tabular}

Sumber : Data diolah, 2020

Pada Tabel 9 dapat dilihat bahwa nilai signifikansi dari variabel work family conflict sebesar 0,593. Nilai signifikan dari variabel kompensasi sebesar 0,097 dan 
nilai signifikan variabel kepuasan kerja family conflict terhadap turnover intention.

sebesar 0,512. Nilai tersebut lebih besar dari 0,05 yang berarti tidak terdapat pengaruh antara variabel bebas terhadap absolute ini:

residual. Dengan demikian, model yang dibuat tidak mengandung gejala heteroskedastisitas

Standard error tidak langsung (indirect effect) atau Sabdihitung denganrumus berikutini.

$\mathrm{Sab}=\sqrt{\mathrm{b}^{2} \mathrm{Sa}^{2}+\mathrm{a}^{2} \mathrm{Sb}^{2}+\mathrm{Sa}^{2} \mathrm{Sb}^{2}}$

Keterangan;

$\mathrm{a}=0,472$

$\mathrm{Sa}=0,067$

$\mathrm{b}=0,409$

$\mathrm{Sb}=0,053$

$\mathrm{Sab}=\sqrt{(0,409)^{2}(0,067)^{2}+(0.472)^{2}(0,053)^{2}+(0,067)^{2}(0,053)^{2}}$ $S \mathrm{ab}=0,027$

Untuk menguji signifikansi pengaruh tidak langsung, maka diperlukan untuk melakukan perhitungan nilai $\mathrm{z}$ dari koefisien ab dengan rumus sebagai berikut:

$$
\begin{aligned}
& Z=\frac{\mathrm{ab}}{S \mathrm{ab}} \ldots \ldots \ldots \ldots \ldots \ldots \ldots \ldots \ldots \\
& Z=\frac{(0,409)(0,472)}{0,038} \\
& Z=7,148
\end{aligned}
$$

Berdasarkan perhitungan $Z$, maka didapatkan nilai $Z$ hitung sebesar 7,148 yang berarti bahwa nilai $\mathrm{Z}$ hitung lebih besar dari $\mathrm{Z}$ tabel sebesar 1,96. Hal ini dapat diartikan bahwa variabel kepuasan kerja mampu memediasi secara signifikan pengaruh antara variabel work
Standard error tidak langsung (indirect

effect) atau Sab dihitung dengan rumus berikut

$S a b=\sqrt{b^{2} \mathrm{Sa}^{2}+\mathrm{a}^{2} \mathrm{Sb}^{2}+\mathrm{Sa}^{2} \mathrm{Sb}^{2}}$

Keterangan:

$\mathrm{a}=0,480$

$\mathrm{Sa}=0,067$

$\mathrm{b}=0,402$

$\mathrm{Sb}=0,053$

$\mathrm{Sab}=\sqrt{(0,402)^{2}(0,067)^{2}+(0.480)^{2}(0,053)^{2}+(0,067)^{2}(0,053)^{2}}$ $\mathrm{Sab}=0,038$

Untuk menguji signifikansi pengaruh tidak langsung, maka diperlukan untuk melakukan perhitungan nilai z dari koefisien $\mathrm{ab}$ dengan rumus sebagai berikut:

$$
\begin{aligned}
& Z=\frac{\mathrm{ab}}{S \mathrm{ab}} \ldots \ldots \ldots \ldots \ldots \ldots \ldots \ldots \ldots \ldots \\
& Z=\frac{(0,480)(0,422)}{0,038} \\
& Z=5,053
\end{aligned}
$$

Berdasarkan perhitungan $\mathrm{Z}$, maka didapatkan nilai $\mathrm{Z}$ hitung sebesar 5,053 yang berarti bahwa nilai $\mathrm{Z}$ hitung lebih besar dari $\mathrm{Z}$ tabel sebesar 1,96. Hal ini dapat diartikan bahwa variabel kepuasan kerja mampu memediasi secara signifikan pengaruh antara variabel kompensasi terhadap turnover intention.

Berdasarkan hasil analisis pengaruh work family conflict terhadap turnover intention diperoleh nilai Signifikansi sebesar 0,000 dengan 
nilai koefisien beta 0,409 bernilai positif. Nilai kompensasi terhadap turnover intention. Signifikansi $0,000<0,05$ mengindikasikan Hasil ini mempunyai arti bahwa kompensasi bahwa $\mathrm{H}_{0}$ ditolak dan $\mathrm{H}_{1}$ diterima. Hasil ini berpengaruh negatif dan signifikan terhadap mempunyai arti bahwa work family conflict turnover intention, dimana dengan semakin berpengaruh positif dan signifikan terhadap baiknya kompensasi yang diberikan perusahaan turnover intention. work family conflict kepada karyawannya maka niat keluar karyawan memiliki pengaruh yang positif dan signifikan akan semakin rendah. Hasil penelitian ini sesuai terhadap turnover intention, dimana pengaruh positif mengisyaratkan apabila work family dengan hipotesis dua (H2) yang diajukan dan sesuai dengan penelitian yang dilakukan oleh conflict yang dialami oleh karyawan meningkat, Widayati \& Yunia (2016); Pranowo (2016); maka turnover intention karyawan juga Artha \& Surya (2017); Artiningrum \& Satrya ikut meningkat. Hasil penelitian ini sesuai dengan hipotesis satu (H1) yang diajukan dan sesuai dengan penelitian yang dilakukan oleh Wulandari \& Adnyani (2016); Dewi dkk (2018); Nanda \& Utama (2015); Chen et al., (2018); Long et al., (2016); Riptiono (2017); Nisa (2016) dalam penelitiannya menunjukan pengaruh positif signifikan antara variabel work family conflict dan turnover intention.

(2016); Chew et al., (2016); Candra et al., (2018); Rubel \& Kee (2015); Fuaidah dkk., (2018) mengungkapkan bahwa kompensasi karyawan berpengaruh negatif dan signifikan terhadap turnover intention.

Berdasarkan hasil analisis pengaruh kepuasan kerja terhadap turnover intention diperoleh nilai Signifikansi sebesar 0,032 dengan nilai koefisien beta $-0,209$ bernilai Berdasarkan hasil analisis pengaruh kompensasi terhadap turnover intention diperoleh nilai Signifikansi sebesar 0,000 dengan nilai koefisien beta $-0,402$ bernilai negatif. Nilai Signifikansi $0,000<0,05$ mengindikasikan bahwa $\mathrm{H}_{0}$ ditolak dan $\mathrm{H}_{1}$ diterima, yang berarti terdapat pengaruh yang signifikan antara negatif. Nilai Signifikansi $0,032<0,05$ mengindikasikan bahwa $\mathrm{H}_{0}$ ditolak dan $\mathrm{H}_{1}$ diterima, yang berarti terdapat pengaruh yang signifikan antara kepuasan kerja terhadap turnover intention Hasil ini mempunyai arti bahwa kepuasan kerja berpengaruh negatif dan signifikan terhadap turnover intention. Dimana 
dengan semakin tingginya tingkat kepuasan kerja yang dirasakan karyawan, maka turnover intention akan menurun. Hasil penelitian ini sesuai dengan hipotesis tiga (H3) yang diajukan dan sesuai dengan penelitian yang dilakukan oleh Rismayanti dkk., (2018); Sathyanarayan \& Lavanya (2018); Lee \& Chelladurai (2017); Zeffane \& Bani (2017); Zhang et al., (2018); Ardiyanti (2019); Turgut et al., (2017); Widyantara \& Ardana (2015); Putra \& Mujiati (2019) menunjukan hasil yang sama dimana kepuasan kerja berpengaruh negative dan signifikan terhadap turnover intention.

Berdasarkan hasil analisis pengaruh work family conflict terhadap kepuasan kerja diperoleh nilai Signifikansi sebesar 0,000 dengan nilai koefisien beta $-0,472$ bernilai negatif. Nilai Signifikansi $0,000<0,05$ mengindikasikan bahwa $\mathrm{H}_{0}$ ditolak dan $\mathrm{H}_{1}$ diterima, yang berarti terdapat pengaruh yang signifikan antara variabel work family conflict dengan kepuasan kerja, dimana hasil ini mempunyai arti bahwa work family conflict berpengaruh negatif dan signifikan terhadap kepusan kerja, hal ini mengisyaratkan dengan semakin tingginya work family conflict yang dialami oleh karyawan makan semakin menurunnya kepuasan kerja yang dirasakan oleh karyawan. Hasil penelitian ini sesuai dengan hipotesis empat (H4) yang diajukan dan sesuai dengan penelitian yang dilakukan oleh Paramita \& Subudi (2017); Mardhika \& Dewi (2019); Ariana \& Riana (2016); Afrilia \& Utami (2018); Zito et al., (2019); Rahman et al., (2018); Yani dkk., (2016) dimana memperoleh hasil work-family conflict memiliki pengaruh yang negatif dan signifikan terhadap kepuasan kerja.

Berdasarkan hasil analisis pengaruh kompensasi terhadap kepuasan kerja diperoleh nilai Signifikansi sebesar 0,000 dengan nilai koefisien beta 0,480 bernilai positif. Nilai Signifikansi $0,000<0,05$ mengindikasikan bahwa $\mathrm{H}_{0}$ ditolak dan $\mathrm{H}_{1}$ diterima, yang berarti terdapat pengaruh yang signifikan antara variabel kompensasi dengan kepuasan kerja. Hasil ini mempunyai arti bahwa kompensasi berpengaruh positif dan signifikan terhadap kepusan kerja, mengisyaratkan bahwa dengan semakin baiknya kompensasi yang diberikan perusahaan kepada karyawan maka akan semakin tinggi pula tingkat kepuasan kerja yang dirasakan oleh karyawan. Hasil penelitian ini sesuai dengan hipotesis lima (H5) yang diajukan dan sesuai dengan penelitian yang dilakukan oleh Potale \& Uhing (2015); 
Akmal \& Tamini (2015); Tantowi dkk (2016); ini sesuai dengan theory yang digunakan yaitu Ramli (2018); Ganesan et al., (2017); Wasistha traditional turnover theory dimana ketika work \& Rahyuda (2018); Nurcahyani \& Adnyani family conflict yang dirasakan oleh karyawan (2016); Setyorini et al., (2018) dimana dalam penelitiannya menyatakan bahwa terdapat pengaruh yang positif dan signifikan antara variabel kompensasi dengan variabel kepuasan kerja.

Hasil analisis kepuasan kerja memediasi pengaruh antara work family conflict terhadap turnover intention diperoleh nilai $\mathrm{Z}$ hitung sebesar 7,148 $>1,96$. Artinya kepuasan kerja mampu memediasi pengaruh work family conflict terhadap turnover intention, mediasi yang terjadi yaitu mediasi parsial, dimana kepuasan kerja dapat langsung berpengaruh terhadap turnover intention, dan dapat juga menjadi variabel penghubung antara variabel work family conflict terhadap turnover intention. Hasil penelitian ini sesuai dengan hipotesis enam (H6) yang diajukan dan sesuai dengan penelitian yang dilakukan oleh Wulandari \& Adnyani (2016); Sakawangi \& Supartha (2017); Paramita \& Subudi (2017); Tariana \& Wibawa (2016); Silvyana \& Wibawa (2019) menyatakan kepuasan kerja memediasi pengaruh workfamily conflict terhadap turnover intention, hasil tinggi, maka hal ini tentu akan menurunkan tingkat kepuasan kerja bagi karyawan, hal ini akan mengarah kepada peningkatan tingkat turnover intention.

Hasil analisis kepuasan kerja memediasi pengaruh antara work family conflict terhadap turnover intention diperoleh nilai $\mathrm{Z}$ hitung sebesar 5,053 >1,96. Artinya kepuasan kerja mampu memediasi pengaruh kompensasi terhadap turnover intention atau dengan kata lain kompensasi berpengaruh secara tidak langsung terhadap turnover intention melalui kepuasan kerja,mediasi yang terjadi yaitu mediasi parsial, dimana kepuasan kerja dapat langsung berpengaruh terhadap turnover intention, dan dapat juga menjadi variabel perantara antara variabel kompensasi terhadap turnover intention. Hasil penelitian ini sesuai dengan hipotesis tujuh (H7) yang diajukan dan sesuai dengan penelitian yang dilakukan oleh Rohmawati dkk., (2017); Rasyid \& Sri (2017); Robbin (2015); Agustin (2018). Hasil ini sejalan dengan theory yang digunakan yaitu traditional turnover theory, dimana ketika kompensasi 
yang diberikan oleh perusahaan baik, maka hal itu akan meningkatkan tingkat kepuasan kerja yang akhirnya akan menurunkan tingkat turnover intention.

\section{SIMPULAN DAN SARAN}

Work family conflict berpengaruh positif dan signifikan terhadap turnover intention. Hal ini menunjukan bahwa jika work family conflict semakin meningkat maka akan meningkatkan pula turnover intention pada karyawan Bank Permata Cabang Dewi Sartika Denpasar.Kompensasi berpengaruh negatif dan signifikan terhadap turnover intention. Hal ini menunjukan bahwa jika kompensasi yang diberikan perusahaan semakin baik maka akan menurunkan turnover intention pada karyawan Bank Permata Cabang Dewi Sartika Denpasar. Kepuasan kerja berpengaruh negatif dan signifikan terhadap turnover intention. Hal ini menunjukan bahwa jika kepuasan kerja semakin meningkat maka akan menurunkan turnover intention pada karyawan Bank Permata Cabang Dewi Sartika Denpasar.Work family conflict berpengaruh negatif dan signifikan terhadap kepusan kerja. Hal ini menunjukan bahwa jika Work family conflict semakin meningkat maka akan menurunkan tingkat kepusan kerja pada karyawan Bank Permata Cabang Dewi Sartika Denpasar.Kompensasi berpengaruh positif dan signifikan terhadap kepusan kerja. Hal ini menunjukan bahwa jika Kompensasi yang diberikan perusahaan semakin baik maka akan meningkatkan pula tingkat kepusan kerja pada karyawan Bank Permata Cabang Dewi Sartika Denpasar.

Kepuasan kerja mampu memediasi secara parsial pengaruh work family conflict terhadap turnover intention pada karyawan Bank Permata Cabang Dewi Sartika Denpasar. Hal ini menunjukan bahwa work family conflict memberikan dampak yang signifikan terhadap turnover intention jika di mediasi oleh kepuasan kerja, yang berarti bahwa pengaruh work family conflict terhadap turnover intention akan diperkuat dengan adannya kepuasan kerja. Kepuasan kerja mampu memediasi secara parsial pengaruh kompensasi terhadap turnover intention pada karyawan Bank Permata Cabang Dewi Sartika Denpasar. Hal ini menunjukan bahwa Kompensasi memberikan dampak yang signifikan terhadap turnover intention jika di mediasi oleh kepuasan kerja, yang berarti bahwa pengaruh kompensasi terhadap turnover 
intention akan diperkuat dengan adannya kepuasan kerja.

Sebaiknya pihak manajemen Bank Permata Cabang Dewi Sartika Denpasar perlu menyediakan fasilitas-fasilitas seperti tempat penitipan anak agar para karyawan yang bekerja di perusahaan dapat juga sekalian menjalankan perannya sebagai orang tua ketika sedang bekerja.

Sebaiknya pihak manajemen Bank Permata Cabang Dewi Sartika Denpasar memperhatikan dan melakukan evaluasi terhadap gaji yang diberikan kepada karyawan, dimana penilaian yang dirasakan karyawan bahwa gaji yang diterima belum sesuai hasil yang diberikan kepasa perusahaan. Hal ini dilakukan agar karyawan merasa dihargai usahanya dalam bekerja sebab gaji yang diterima telah sesuai dengan hasil pekerjaan yang diberikan kepada perusahaan, sehingga dapat menurunkan turnover intention pada Bank Permata Cabang Dewi Sartika Denpasar.

Sebaiknya pihak manajemen Bank Permata Cabang Dewi Sartika Denpasar perlu memperhatikan dan mengevaluasi sistem promosi jabatan yang diberikan kepada karyawan, agar karyawan merasa perusahaan telah memberikan keadilan dalam hal promosi jabatan sehingga karyawan akan lebih semangat dalam bekerja dan akan menurunkan turnover intention pada Bank Permata Cabang Dewi Sartika Denpasar.

Penelitian selanjutnya diharapkan untuk melakukan penelitian dengan cakupan yang lebih luas seperti, mencari lokasi penelitian selain perbankan, menggunakan sampel penelitian yang lebih banyak, menambah variabel-variabel lain diluar penelitian ini, menggunakan teknik analisis data yang berbeda (PLS atau SEM), serta diharapkan mampu menambah referensi terhadap variabel yang akan diteliti

\section{REFERENSI}

Afrilia, L. D., \& Utami, H. N. (2018). Pengaruh Work-Family Conflict terhadap Kepuasan Kerja dan Kinerja (Studi pada Karyawan Wanita Rumah Sakit Permata Bunda Malang). Jurnal Administrasi Bisnis, 55(2), 48-56. http:// administrasibisnis.studentjournal.ub.ac. id/index.php/jab/article/view/2270

Agustin, D. I. (2018). Pengaruh Kompensasi Finansial Langsung terhadap Turnover Intention dengan Kepuasan Kerja sebagai Variabel Intervening (pada Ratu Swalayan Dampit Kabupaten Malang). Manajemen Bisnis, 8(2), 75-83. https:// doi.org/10.22219/jmb.v8i2.7057

Akmal, A., \& Tamini, I. (2015). Pengaruh Kompensasi Terhadap Kepuasan Kerja Karyawan Gayamakmur Mobil Medan. 
Jurnal Bisnis Administrasi, 04(02), 59-68. https://ejournal.bsi.ac.id/ejurnal/ index.php/perspektif/article/view/4744

Ardiyanti, I. (2019). Pengaruh Kelelahan Kerja dan Kepuasan Kerja Terhadap Turnover Intention. Jurnal Inspirasi Bisnis Dan Manajemen, 3(1), 11-20. https://doi. org/10.33603/jibm.v3i1.2190

Ariana, I. W. J., \& Riana, I. G. (2016). Pengaruh Work-Family Conflict, Keterlibatan Kerja dan Stres Kerja terhadap Kepuasan Kerja Karyawan. E-Jurnal Manajemen Universitas Udayana, 5(7), 46304659. https://ojs.unud.ac.id/index.php/ Manajemen/article/view/22246

Arta, I. G. N. W., \& Surya, I. B. K. (2017). Pengaruh Kompensasi terhadap Komitmen Organisasional dan Turnover Intention pada Agent Pru Megas. E-Jurnal Manajemen Universitas Udayana, 6(8), 4156-4184. https:// ojs.unud.ac.id/index.php/Manajemen/ article/view/31026

Artiningrum, B., \& Satrya, A. (2016). Analisis Pengaruh Career Management, Training Satisfaction, Pay Satisfaction terhadap Turnover Intention dan Peran Mediasi Organizational Engagement pada Karyawan Sektor Perbankan. Jurnal Manajemen Dan Bisnis Sriwijaya, 14(3), 337-352. https://doi.org/10.29259/jmbs. v14i3.3992

Candra, D. M., Hana, S. W. L., \& Wulandari, D. (2018). Compensation and Turnover Intention in Coal Mining Support Companies in South Kalimantan. International Journal of Scientific and Technology Research, 7(4), 202-205. https://www.ijstr.org/paper-references. php?ref=IJSTR-0418-18903

Chen, H., Ayoun, B., \& Eyoun, K. (2018). Work-Family Conflict and Turnover Intentions: A Study Comparing China and U.S. Hotel Employees. Journal of Human Resources in Hospitality and
Tourism, 17(2), 247-269. https://doi.org /10.1080/15332845.2017.1406272

Chew, H. G., Ng, K. Y. N., \& Fan, S. W. (2016). Effects of Alternative Opportunities and Compensation on Turnover Intention of Singapore PMET. International Journal of Humanities and Social Sciences, 10(3), 720-728. https://doi.org/10.5281/ zenodo. 1111905

Dewi, K., Minarsih, M. M., \& Wahyono, E. H. (2018). Pengaruh Work-Family Conflict, Kepemimpinan dan Lingkungan Kerja Terhadap Turnover Intention Karyawan Wanita dengan Kepuasan Kerja sebagai Variabel Intervening (Studi Kasus Pada Bagian Sewing PT. Ungaran Sari Garments Semarang). Journal Of Management, 4(4). https://jurnal. unpand.ac.id/index.php/MS/article/ view/1123

Fuaidah, N. R., Sunuharyo, B. ., \& Aini, E. K. (2018). Pengaruh Kompensasi Karyawan dan Lingkungan Kerja Karyawan terhadap Turnover Intention (Studi pada Karyawan Auto2000 Malang-Sutoyo). Jurnal Administrasi Bisnis (JAB), 60(2), 192-198. http://administrasibisnis. studentjournal.ub.ac.id/index.php/jab/ article/view/2525

Ganesan, J., Ling, W. X., \& Mun, L. k. (2017). Determinants of Employee Job Satisfaction in the Malaysian Manufacturing Sector. In Medwell Journals: Vols. 12 (10-12) (pp. 449454). https://medwelljournals.com/ abstract/?doi=rjasci.2017.449.454

Jamadin, N., Mohamad, S., Syarkawi, Z., \& Noordin, F. (2015). Work Family Conflict and Stress: Evidence from Malaysia. Journal of Economics, Business and Management, 3, (2), 309-312. https:// doi.org/10.7763/JOEBM.2015.V3.200

Lee, Y. H., \& Chelladurai, P. (2017). Emotional Intelligence, Emotional Labor, Coach Burnout, Job Satisfaction, and Turnover 
Intention in Sport Leadership. European Sport Management Quarterly, 18(4), 393-412. https://doi.org/10.1080/16184 742.2017.1406971

Long, C. S., Azami, A., Kowang, T. O., \& Fei, G. C. (2016). An Analysis on The Relationship Between Work Family Conflict and Turnover Intention: A Case Study in A Manufacturing Company in Malaysia. In International Business Management (Vol. 10, Issue 3, pp. 176-182). https://doi.org/10.3923/ ibm.2016.176.182

Lu, Y., Hu, X. M., Huang, X. L., Zhuang, X. D., Guo, P., Feng, L. F., Hu, W., Chen, L., Zou, H., \& Hao, Y. T. (2016). The Relationship Between Job Satisfaction, Work Stress, Work-Family Conflict, and Turnover Intention among Physicians in Guangdong, China: A Cross-Sectional Study. BMJ Open. https://10.1136/ bmjopen-2016-014894

Mangkunegara, A. P. (2005). Evaluasi Kinerja Sumber Daya Manusia. Bandung: PT. Rcfika Aditama.

Mardhika, i. P. A., \& Dewi, A. A. S. K. (2019). Pengaruh Konflik Pekerjaan Keluarga terhadap Keinginan untuk Keluar melalui Mediasi Kepuasan Kerja. E-Jurnal Manajemen, 8(6), 3333-3359. https:// doi.org/10.24843/EJMUNUD.2019. v08.i05.p02

Nanda, N. L. N. K., \& Utama, I. W. M. (2015). Pengaruh Konflik Kerja-Keluarga dan Kepuasan Kerja Terhadap Tingkat Turnover Intention Karyawan Pada Restoran Pizza Hut Mall Bali Galeria. E-Jurnal Manajemen Universitas Udayana, 4(9), 2461-2477. https:// ojs.unud.ac.id/index.php/Manajemen/ article/view/12879

Nisa, N. H., \& Malik, N. (2016). Pengaruh Work Overload dan Work Family Conflict terhadap Turnover Intention yang Dimediasi oleh Work Exhaustion.
Journal of Innovation in Business and Economics, 7(1), 67-76. https://doi. org/10.22219/jibe.vol7.no1.67-76

Nurcahyani, N. M., \& Adnyani, I. G. A. D. A. (2016). Pengaruh Kompensasi dan Motivasi terhadap Kinerja Karyawan dengan Kepuasan Kerja sebagai Variabel Intervening. E-Jurnal Manajemen Unud, 5(1), 500-532. https://ojs.unud. ac.id/index.php/Manajemen/article/ view/16159

Paramita, I. G. A. M., \& Subudi, M. (2017). Pengaruh Konflik Pekerjaan-Keluarga terhadap Turnover Intention melalui Mediasi Kepuasan Kerja pada Hoki Bank Cabang Gatot Subroto. E-Jurnal Manajemen Universitas Udayana, 6(12), 6441-6470. https://ojs.unud.ac.id/index. php/Manajemen/article/view/33694

Potale, R., \& Uhing, Y. (2015). Pengaruh Kompensasi dan Stres Kerja terhadap Kepuasan Kerja Karyawan pada PT. Bank Sulut Cabang Utama Manado. Jurnal Riset Ekonomi, Manajemen, Bisnis Dan Akuntansi, 3(1), 63-73. https://doi. org/10.35794/emba.v3i1.6567

Pranowo, R. S. (2016). Pengaruh Kepuasan Kerja, Lingkungan Kerja, dan Kompensasi terhadap Turnover Intention Karyawan dengan Lama Kerja sebagai Variabel Pemoderasi (Studi Kasus pada CV. Sukses Sejati Computama). Jurnal Profita, 4, 1-11. http://journal.student. uny.ac.id/ojs/index.php/profita/article/ view $/ 5630$

Putra, D. M. B. A., \& Mujiati, N. W. (2019). Peran Kepuasan Kerja dalam Memediasi Pengaruh Stres Kerja dan Motivasi Kerja terhadap Turnover Intention. E-Jurnal Manajemen, 8(7), 4045-4072. https:// doi.org/10.24843/EJMUNUD.2019. v08.i07.p02

Putra, D. G. E. K., \& Surya, I. B. K. (2016) Pengaruh Kepuasan Gaji terhadap Turnover Intention dengan Komitmen 
Organisasional sebagai Mediasi pada Rumah Sakit Umum Premagana. E-Jurnal Manajemen Unud, 5(7), 42814308. https://ojs.unud.ac.id/index.php/ Manajemen/article/view/21386

Putra, I. A. G. E. M., \& Wibawa, I. M. A. (2015). Pengaruh Kepuasan Kerja terhadap Turnover Intention dengan Komitmen Organisasi sebagai Variabel Intervening pada PT. Autobagus Rent Car Bali. E-Jurnal Manajemen Universitas Udayana, 4(4), 1100-1118. https://doi. org/10.24843/ejmunud.2020.v09.i04. p20

Rahman, M. M., Ali, N. A., Mansor, Z. D., Jantan, A. H., Samuel, A. B., Alam, M. K., \& Hosen, S. (2018). Work-Family Conflict and Job Satisfaction: The Moderating Effects of Gender. Academy of Strategic Management Journal, 17(5), 1-6. https://www.researchgate. net/publication/328171784_Workfamily_conflict_and_Job_Satisfaction_ The_moderating_effects_of_gender

Ramli, A. H. (2018). Compensation, Job Satisfaction and Employee Performance in Health Services. Business and Entrepreneurial Review, 18(2), 177-186. https://doi.org/10.25105/ber.v18i2.5335

Rasyid, A. A., \& Indarti, S. (2017). Pengaruh Komitmen Organisasional dan Kompensasi terhadap Turn Over Intention dengan Kepuasan Kerja sebagai Variabel Intervening pada PT. Persada Lines Pekanbaru. Jurnal Tepak Manajemen Bisnis, 9(3), 36-53. https:// jtmb.ejournal.unri.ac.id/index.php/ JTMB

Riptiono, S. (2019). Analisis Pengaruh Work Family Conflict dan Family Work Conflict terhadap Turnover Intention dengan Job Strees sebagai Mediasi (Studi Pada Karyawan Wanita Cv. Tiga Mutiara). Managament Insight: Jurnal Ilmiah Manajemen, 12(2), 13-22.https:// doi.org/10.33369/insight.12.2.13-22

Rismayanti, R. D., Musadieq, M. A., \& Aini, E. K. (2018). Pengaruh Kepuasan Kerja terhadap Turnover Intention serta Dampaknya pada Kinerja Karyawan (Studi pada Karyawan Tetap Pg Kebon Agung Malang). Jurnal Administrasi Bisnis, 61(2), 127-136. http:// administrasibisnis.studentjournal.ub.ac. id/index.php/jab/article/view/2581

Robbins, S. P. \& Judge. (2007). Perilaku Organisasi. Jakarta: Salemba Empat.

Rohmawati, I., Wulan, H. S., \& Dhiana, P. (2017). Pengaruh Gaya Kepemimpinan Transformasional dan Kompensasi Terhadap Intensitas Turnover yang Dimediasi Kepuasan Kerja (Studi Pada Karyawan Bagian Sewing PT Maxmoda Indo Global). Journal Of Management, 3(3), 154-162. https://jurnal.unpand. ac.id/index.php/MS/article/view/711

Rubel, M. R. B., \& Kee, D. M. H. (2015). High Commitment Compensation Practices and Employee Turnover Intention: Mediating Role of Job Satisfaction. Mediterranean Journal of Social Sciences, 6(6), 321-332. https://doi. org/10.5901/mjss.2015.v6n6s4p321

Sakawangi, N. D. I. S., \& Supartha, W. G. (2017). Peran Mediasi Kepuasan Kerja pada Pengaruh Konflik PekerjaanKeluarga terhadap Turnover Intention Karyawan Wanita. E-Jurnal Manajemen Universitas Udayana, 6(9), 4744 4771. https://ojs.unud.ac.id/index.php/ Manajemen/article/view/31422

Sathyanarayan, K., \& Lavanya, B. L. (2018). Effect of Organizational Commitment, Motivation, Attitude Towards Work on Job Satisfaction, Job Performance and Turnover Intention"- Vuca Perspective. Journal of Management, 5(4), 445-457.

Setyorini, R. W., Yuesti, A., \& Landra, N. (2018). The Effect of Situational Leadership Style and Compensation 
to Employee Performance with Job Satisfaction as Intervening Variable at PT Bank Rakyat Indonesia (Persero), Tbk Denpasar Branch. International Journal of Contemporary Research and Review, 9(08), 20974-20985. https:// doi.org/10.15520/ijcrr/2018/9/08/570

Silvyana, N. P. M., \& Wibawa, I. M. A. (2019). Peran Mediasi Kepuasan Kerja pada Pengaruh Work-Family Conflict terhadap Turnover Intention Kutabex Beach Front. $E, 8(10), 6322-6345$. https://doi. org/10.24843/EJMUNUD.2019.v08. i10.p23

Sutrisno, E. (2009). Manajemen Sumber Daya Manusia (Edisi Pertama) . Jakarta: Prenandamedia Group.

Tantowi, A., Said, L. R., \& Rahmawati, R. (2016). Pengaruh Kompensasi Finansial Dan Non Finansial Terhadap Kepuasan Kerja Serta Dampaknya Terhadap Turnover Intention Pada Pelaut Di Pt . Maritim Barito Perkasa Banjarmasin. Jurnal Wawasan Manajemen, 4(1), 1122. http://jwm.ulm.ac.id/id/index.php/ jwm/article/view/74

Tariana, I. W. A., \& Wibawa, I. M. A. (2016). Peran Mediasi Kepuasan Kerja Dalam Pengaruh Work Family Conflict dan Turnover Intention Pada Karyawan Wanita. E-Jurnal Manajemen Unud, 5(9), 2531975433-2531975461. https:// ojs.unud.ac.id/index.php/Manajemen/ article/view/19978

Turgut, H., Bekmezci, M., \& Ateş, M. F. (2017). The Moderating Role of Job Satisfaction on the Relationship between Servant Leadership and Turnover Intention. Journal of Business Research - Turk, 9(2), 300-314. https://doi.org/10.20491/ isarder.2017.273

Wasistha, C. G. N., \& Rahyuda, A. G. (2018). Pengaruh Kompensasi, Gaya Kepemimpinan Transformasional dan Lingkungan Kerja Fisik terhadap
Kepuasan Kerja Pegawai. E-Jurnal Manajemen Universitas Udayana, 7(12), 6901-6931. https://doi.org/10.24843/ ejmunud.2018.v07.i12.p19

Widayati, C., \& Yunia, Y. (2016). Pengaruh Kompensasi dan Budaya Organisasi terhadap Turnover Intention. Jurnal Manajemen, 20(3), 387-401. https://doi. org/10.24912/jm.v20i3.14

Widyantara, I. B. P., \& Ardana, I. K. (2015). Pengaruh Kepuasan Kerja dan Komitmen Organisasi terhadap Intensitas Turnover Karyawan. E-Jurnal Manajemen Universitas Udayana, 4(6), 1670-1683. https://ojs.unud.ac.id/index. php/Manajemen/article/view/12404

Wulandari, I. A. D., \& Adnyani, I. G. A. D. (2016). Pengaruh Work Family Conflict terhadap Turnover Intention melalui Mediasi Kepuasan Kerja pada Hotel Grand Inna Kuta. E-Jurnal Manajemen Universitas Udayana, 5(10), 61466173. https://ojs.unud.ac.id/index.php/ Manajemen/article/view/20440

Yani, N. W. M. S. A., Sudibya, I. G. A., \& Rahyuda, A. G. (2016). Pengaruh WorkFamily Conflict dan Stres Kerja terhadap Kepuasan Kerja dan Turnover Intention Karyawan Wanita. E-Jurnal Ekonomi Dan Bisnis Universitas Udayana, 5(3), 629-658. https://www.neliti.com/ publications/44800/pengaruh-workfamily-conflict-dan-stres...

Yudhistira, E. R., \& Pradana, B. I. (2016). Pengaruh Kompensasi terhadap Turnover Intention dengan Kepuasan Kerja sebagai Variabel Mediasi (Studi pada PG Kebon Agung). Jurnal Ilimiah Mahasiswa FEB Universitas Brawijaya, 4(2), 1-12. https://jimfeb.ub.ac.id/index. php/jimfeb/article/view/3057

Zeffane, R., \& Melhem, S. J. B. (2017). Trust, Job Satisfaction, Perceived Organizational Performance and Turnover Intention. Employee Relations, 39(7), 1148-1167. 
https://doi.org/10.1108/ER-06-20170135

Zhang, W., Meng, H., Yang, S., \& Liu, D. (2018). The Influence of Professional Identity, Job Satisfaction, and Work Engagement on Turnover Intention among Township Health Inspectors in China. International Journal of Environmental Research and Public Health, 15(5). https://doi. org/10.3390/ijerph15050988

Zito, M., Colombo, L., Borgogni, L., Callea, A., Cenciotti, R., Ingusci, E., \& Cortese, C. G. (2019). The Nature of Job Crafting: Positive and Negative Relations with Job Satisfaction and Work-Family Conflict. International Journal of Environmental Research and Public Health, 16(7). https://doi.org/10.3390/ijerph16071176 